\title{
Penggunaan Metode Ceramah Variasi Yang Disertai Kemampuan Orientasi Terhadap Peningkatan Kualitas Pembelajaran Ekonomi Siswa Kelas X-8 SMAN 1 Paciran Lamongan
}

\author{
Saiful Arif \\ Sekolah Menengah Atas Negeri 1 Paciran Lamongan, Indonesia
}

Abstract: Based on teacher observations identified that students of class $X$ 8 SMAN 1 Paciran Lamongan in receiving subject matter from teachers in general are still unclear or vague, so the following problems are formulated: Is there any influence of using the variety lecture method accompanied by the ability of orientation towards learning outcomes Economics of class X-8 students of SMAN 1 Paciran Lamongan in clarifying understanding about something and to prevent verbalism?

The purpose of this class action research aims to familiarize the teacher in presenting economic subject material with variety lecture methods so that students are able to develop special attitudes and skills by thinking critically and creatively in seeing human relationships with the surrounding environment.

The research took place at SMAN 1 Paciran Lamongan, the activity began with preparations to form 3 groups. Action research planning in each cycle is arranged together based on the observations and reflections of the teacher. Each cycle includes the stages of observation and action and development planning.

The conclusion of the above discussion is (I) Conventional methods in $C A R$ in the field of Economics less influence students to further improve their learning outcomes, (2) Every class action using the lecture method variations accompanied by orientation can foster students' courage to understand, make examples that are almost similar to those in the reading, as well as the ability to ask questions compared to using conventional methods, (3) The acquisition of group student learning outcomes taught using the lecture method variations accompanied by better orientation than the group of students who are taught conventionally.

Keywords: variety lectures, economics

\section{Pendahuluan}

Usaha pemerintah terhadap bidang pendidikan mengarahkan sasaran utamanya kepada pendidikan tingkat dasar dan menengah, dengan tujuan antara lain agar anak-anak mendapat kesempatan belajar dan tertampung seluruhnya di sekolah. 
Dengan demikian, pada akhirnya tidak lagi terdapat bangsa Indonesia yang buta huruf.

Kebijaksanaan Depdiknas yang dituangkan dalam Kurikulum menyatakan, bahwa dalam penyelenggaraan kegiatan belajar mengajar hendaknya memanfaatkan segala sumber daya yang meliputi sumber daya manusia, pesan, orang, bahan peralatan dan latar atau lingkungan. Berangkat dari hal tersebut diatas, maka untuk meningkatkan kualitas proses belajar mengajar, berbagai upaya terus dilakukan dengan cara menyediakan fasilitas pendidikan untuk menampung anak-anak sekolah. Usaha tersebut perlu menjangkau kelompok masyarakat kurang mampu, yang cacat agar merekapun mendapatkan kesempatan belajar sesuai dengan UU Sisdiknas.

Ekonomi adalah suatu program pembelajaran yang merupakan keseluruhan persoalan interaksi manusia dengan lingkungan, baik fisik maupun dalam lingkungan sosial yang bahannya merupakan paduan dari berbagai disiplin ilmu sosial.

Dalam keseluruhan kegiatan mengajar bidang studi tersebut diatas, dapat dinyatakan bahwa komponen metode memainkan peranan yang sangat penting, tanpa metode mengajar yang tepat seluruh proses dari hasil belajar akan sia-sia belaka dan masing-masing metode memiliki kebaikan dan kelemahan. Untuk itu penggunaan metode harus disesuaikan dengan tujuan pengajaran dan situasi pada waktu berlangsungnya pengajarn.

\section{Rumusan Masalah}

Adakah pengaruh penggunaan metode ceramah variasi yang disertai dengan kemampuan orientasi terhadap hasil belajar Ekonomi siswa kelas X-8 SMAN 1 Paciran Lamongan dalam memperjelas pengertian tentang sesuatu dan untuk mencegah verbalisme?

\section{Tujuan Penelitian}

Berdasarkan rumusan masalah diatas, maka tujuan penelitian tindakan kelas ini bertujuan membiasakan guru dalam menyampaikan materi pelajaran Ekonomi dengan metode ceramah variasi sehingga siswa mampu untuk 
mengembangkan sikap dan ketrampilan khusus dengan berfikir kritis dan kreatif dalam melihat hubungan manusia dengan lingkungan yang ada disekitarnya.

\section{Kajianan Pustaka}

\section{Metode Mengajar}

Ada beberapa metode yang dapat digunakan sehingga para siswa tidak merasa bosan / jenuh hanya satu metode saja. Pemilihan metode tertentu dengan berbagai ragamnya tetap harus berkaitan dengan karakteristik tujuan pendidikan yang hendak dicapai. Metode mengajar diantaranya sebagai berikut :

\section{Metode Bermain Peran}

Bermain peran adalah "Salah satu bentuk permainan pendidikan yang dipakai untuk menjelaskan perasaan, sikap, tingkah laku dan nilai dengan tujuan untuk menghayati perasaan, sudut pandangan dan cara berfikir orang lain membayangkan diri sendiri seperti dalam keadaan orang lain.

2. Metode Ceramah Bervariasi

Metode ceramah ialah suatu metode didalam pendidikan dimana cara menyampaikan pengertian-pengertian materi kepada anak didik dengan jalan penerangan dan penuntunan secara lisan disertai dengan demonstrasi. Penggunaan metode ini untuk mengetahui bagaimana prosesnya, bagaimana hal tersebut dapat terjadi sehingga akan menarik minat dan perhatian anak dalam kegiatan belajar.

3. Metode Simulasi

Manfaat penggunaan metode simulasi ini adalah untuk meningkatkan aktifitas belajar siswa dengan melibatkan diri dalam mempelajari situasi yang hampir serupa dengan kejadian yang sebenarnya, memberikan motivasi untuk bekerja sama dalam kelompok dan melatih memahami dan menghargai pendapat, peranan orang lain.

4. Metode Tanya Jawab

Metode tanya jawab adalah suatu cara untuk menyajikan bahan pelajaran dalam bentuk pertanyaan dari guru yang harus dijawab oleh siswa atau sebaliknya pertanyaan dari siswa yang harus dijawab oleh guru baik secara lisan atau tertulis. 


\section{Metode Inkuiri}

Inkuiri adalah suatu kegiatan atau penelaahan sesuatu dengan cara mencari kesimpulan, keyakinan tertentu melalui proses berfikir dan penelaahan secara teratur, runtut dan bisa diterima oleh akal.

6. Metode Pemecahan Masalah (Problem Solving)

Problem solving adalah suatu metode dalam pendidikan dan pengajaran dengan jalan melatih anak-anak untuk menghadapi masalah-masalah dari yang paling sederhana sampai kepada yang sulit.

7. Metode Karyawisata

Metode karyawisata adalah suatu metode pengajaran yang dilaksanakan dengan jalan mengajak anak-anak keluar kelas untuk dapat memperlihatkan hal-hal atau peristiwa yang ada hubungannya dengan bahan pelajaran.

\section{Metode Diskusi}

Metode diskusi adalah suatu metode didalam mempelajari bahan atau menyampaikan bahan dengan jalan mendiskusikannya, sehingga berakibat menimbulkan pengertian serta perubahan tingkah laku murid.

9. Metode Permainan (Game)

Metode permainan merupakan cara penyajian dimana siswa melakukan permainan atau memperoleh atau menemukan pengertian atau konsep tertentu.

Metode ini bertujuan untuk mengajarkan konsep, menanamkan nilai dan memecahkan masalah serta bermanfaat untuk membangkitkan minat siswa, memupuk dan mengembangkan kreatifitas siswa.

\section{Materi Pelajaran Ekonomi}

Ekonomi adalah suatu program pembelajaran yang merupakan keseluruhan persoalan interaksi manusia dengan lingkungan, baik fisik maupun dalam lingkungan sosial yang bahannya merupakan paduan dari berbagai disiplin ilmu sosial. 


\section{Rancangan Penelitian Tindakan Kelas}

Penelitian mengambil tempat di SMAN 1 Paciran Lamongan kelas X-8. Kegiatan penelitian ini direncanakan mulai September sampai dengan Oktober 2018, dengan diawali kegiatan persiapan membentuk menjadi 2 kegiatan. Sebagai tahap awal dengan cara pendataan permasalahan dan tindakan yang telah dilaksanakan oleh guru, kemudian dilanjutkan membahas kerja masing-masing kelompok tersebut serta merencanakan dan menetapkan tindakan bersama-sama tim peneliti. Proses penelitian putaran I atau siklus I pada minggu ketiga Agustus sampai minggu pertama September 2018. Proses penelitian putaran II atau siklus II dilaksanakan pada minggu kedua September sampai dengan minggu ketiga September 2018. Proses penelitian putaran III atau siklus III pada minggu pertama dan kedua Oktober 2018.

\section{Pelaksanaan Dan Hasil Penelitian}

\section{Perencanaan Tindakan}

Penelitian ini melalui siklus yang berdaur ulang dan berkelanjutan serta direncanakan dengan melaksanakan tiga siklus. Setiap siklus dengan tiga tindakan yaitu penanaman konsep, pengertian ekonomi melalui rangsangan cerita dan mengemukakan pendapat, penciptaan kondisi dan pemberian kesempatan untuk bertanya kepada guru dengan wujud pengembangan belajar kreatif dan mengoptimalkan media yang ada di sekolah serta pemberian motivasi.

\section{Implementasi Tindakan}

Siklus I

Tindakan I : Guru menanamkan pentingnya pembagian waktu, sumber daya alam dan pengangkutan serta komunikasi dengan menimbulkan rangsangan cerita pada gambar dan contoh-contoh.

Tindakan II : Menyusun rencana pembelajaran dan melaksanakannya dengan pemberian kesempatan kepada siswa untuk bertanya jawab tentang isi bacaan serta meminta murid untuk menceritakan gambar yang ada dalam bacaan tersebut.

Tindakan III : Memotivasi baik secara verbal maupun non verbal. 
Siklus II

Tindakan I : Menanamkan pentingnya bertanya dengan stimulasi atau rangsangan cerita.

Menugaskan anak untuk mempelajari dan mempersiapkan beberapa pertanyaan untuk pertemuan berikutnya.

Tindakan II : Merencanakan pembelajaran dan melaksanakan dengan metode tanya jawab tentang materi pembagian waktu, sumber daya alam, pengangkutan, komunikasi, bangun datar, bilangan pecahan dan pengukuran sudut.

Tindakan III : Pemberian motivasi dengan memberi nilai tambah pada anak yang mengerti dan memahami materi ekonomi secara keseluruhan.

Siklus III

Tindakan I : Mengingatkan pentingnya bertanya dengan rangsangan atau stimulus cerita.

Menugaskan siswa untuk mempelajari bahan pelajaran untuk pertemuan berikutnya serta menyiapkan beberapa pertanyaan.

Tindakan II : Merancang dan melaksanakan pembelajaran tentang perangkutan dan komunikasi dengan lebih mengoptimalkan ceramah bervariasi dan diskusi disertai dengan tanya jawab untuk lebih merangsang dalam mengemukakan gagasan-gagasan diterapkan model pembelajaran kreatif.

\section{Siklus IV}

Tindakan I : Mengingatkan pentingnya bertanya dengan rangsangan atau stimulus tentang pentingnya bisa membaca dan menulis bangun datar dan bilangan pecahan.

Tindakan II : Untuk menunjukkan keberanian siswa dengan merangsang dan melaksanakan pembelajaran dengan bertanya.

Tindakan III : Memberi pujian dan tindakan berani bagi siswa yang mampu untuk menceritakan kembali isi bacaan dan bertanya tentang hal-hal yang berkaitan dengan hal-hal tertentu. 


\section{Monitoring Penelitian}

Tindakan pada setiap siklus dipantau oleh anggota peneliti yang lain. Dalam memantau setiap tindakan tersebut dengan menggunakan lembar observasi sebagai alat bantu.

Pemantau juga mencatat peristiwa-peristiwa reaksi siswa yang muncul, mendukung atau menghambat. Disamping itu guru selaku aktor utama dalam penelitian ini juga mencatat setiap reaksi siswa terhadap tindakan yang diberikan.

\section{Refleksi Hasil Penelitian}

Setelah melaksanakan dan menyelesaikan tindakan pada setiap siklus tim peneliti melakukan diskusi dan mengadakan refleksi. Masing-masing dapat memberikan laporan hasil pantauannya dan guru sendiri dengan bantuan peneliti yang lain merefleksi pembelajaran yang telah dilakukannya.

\section{Kesimpulan Dan Saran}

\section{Kesimpulan}

1. Metode konvensional dalam PTK pada bidang studi Ekonomi kelas X-8 SMAN 1 Paciran Lamongan kurang mempengaruhi siswa untuk lebih meningkatkan hasil belajarnya.

2. Setiap tindakan kelas dengan menggunakan metode ceramah variasi disertai dengan orientasi dapat menumbuhkan keberanian siswa untuk memahami, membuat contoh yang hampir mirip dengan yang ada pada bacaan, serta kemampuan untuk bertanya dibandingkan dengan menggunakan metode konvensional.

\section{Saran}

Berdasarkan pada kesimpulan diatas, maka untuk meningkatkan prestasi siswa kelas X-8 SMAN 1 Paciran Lamongan, hendaknya diperhatikan adalah metode yang tepat untuk diterapkan dalam pembelajaran Ekonomi. 


\section{Daftar Pustaka}

Afifudin, dkk. 1988. Psikologi Pendidikan Anak Usia Sekolah Dasar. Solo: Harapan Massa

Azwar, Saifudin. 1999. Metode Penelitian. Yogyakarta : Pustaka BelajarArikunto, Suharsimi, 1999. Dasar-dasar Evaluasi Pendidikan, Jakarta : Bumi Aksara

C.E. Beeby, 1982. Pendidikan di Indonesia Penilaian dan Pedoman Perencanaan, Jakarta : LP3ES

Djamarah, Syaiful Bahri \& Zain, Aswan. 1966. Strategi Belajar Mengajar. Jakarta : Rineka Cipta

Gagne, Robert. M. 1985. The Conditions of Learning and Theory of Instruction. Canada. Holf, Rinchart and Winston, Inc

H.A.R. Tilaar, 1999. Pendidikan, Kebudayaan dan Masyarakat Madani Indonesia Strategi Reformasi Pendidikan Nasional. Bandung : PT. Remaja Rosdakarya

Muhibbin Syah, M.Ed. 2004. Psikologi Belajar. Jakarta : Raja Grafindo Persada.

M. Khafid, Suyati. 2004. Matematika 5B. Jakarta : Erlangga

M. Khafid, Suyati. 2004. Matematika 6B. Jakarta :. Erlangga

Nasution. 2000. Berbagai Pendekatan Dalam Program Belajar dan Mengajar. Jakarta : PT. Bumi Aksara

Sapariadi, Sutarno, F.G. Sinaga, I Nyoman Subagya. 1982. Mengapa Berkelainan Perlu Mendapat Pendidikan. Jakarta : Balai Pustaka

Aqib, Zainal 2006, Penelitian Tindakan Kelas, Bandung, Yrama Widya 